\title{
Identifying Some Sweet Maize Inbred Lines by Using Some Growing Parameters
}

\author{
Elif Özdemir ${ }^{1}$ and Bayram Sade ${ }^{1}$ \\ ${ }^{1}$ Selcuk University; Agriculture Faculty, Crop Science Department, Konya/TURKEY
}

\begin{abstract}
The study was conducted at Selcuk University Agriculture Faculty Crop Science Department in Konya/Turkey during 2013. Seeds obtained from 38 sweet maize inbred lines belong to S5 used that have been improved by S.U.A.F. Crop science Department faculty members. Lumina and Merit hybrid maize varieties were used as standards. The study was conducted according to "Augmented Experimental Design" as four blocks at S.U.A.F. Crop Science Department Prof. Abdulkadir AKCIN experimental area. When at the blocks all inbred lines were exemplify with an unrepeated line, standard hybrid maize varieties were repeated at all blocks. Tasseling time, silking, first ear height, stem thickness, leaf angle, and plant leaf number values used to determine growing parameters of lines. All analyses were done at 5 plants at all lines and standards during tasseling time. Sweet maize inbred lines tasseling times varied between 82,67 (4.27.3) days to 60,67 (4.14.1) days, silking duration ranged from 89 days (4.11.3) to 41 days (4.26.4). It was recorded that first ear height values changed $64,10 \mathrm{~cm}(4.25 .1)$ to $34,10 \mathrm{~cm}$ (4.17.3). Sweet maize inbred lines stem thickness values varied between $2,39 \mathrm{~cm}$ (4.13.1) to $1,07 \mathrm{~cm}$ (4.4.3), leaf angle values changed $69,14^{\circ}$ (4.6.3) to $19,14^{\circ}$ (4.4.3). Plant leaf number values were changed 12,76 (4.13.1) to 6,74 (4.14.1). As a result of the study a lot of morphological and phenological characteristics of lines were determined comparatively with hybrid maize varieties, at this way an important variation is detected with all of those identified parameters. It can be told that those lines can be source of successful hybrid maize varieties in the future.
\end{abstract}

Keywords: Sweet Maize, Inbred Lines, Growth Parameters, Augmented Experimental Design

\section{Introduction}

Maize is important for human and animal nutrition because of it's rich nutrient include. It is also important for animal feeding and source for sugar base starch and oil industry. Maize that is produced in Turkey is consumed in Turkey. Because of livestock production development and intensive agriculture, demand of maize is increased day by day. Maize production values increased each day also according to use of hybrid maize seeds [1]. One of the ways to improve yield in agriculture is developing high yield potential varieties and to use plant genetic potential maximum by cultural precautions. In our country potential agricultural areas limited so it is not possible to increase amount of area harvested. So obtaining high yield values can be possible only with increasing yield potential maximum [2][3]. Obtaining high yield potential and varieties superior properties, maize breeding studies must be go on. Identifying genetic differences between parent lines in order to get high heterosis in obtaining hybrid cultivars in open-pollinated plants like maize is very important. Because of this, breeders develop source populations from different heterotic groups and perform crossbreeding among these populations [4]. To improve sturdy hybrid maize varieties, it is necessary to improve strong lines. Aim of this study is determination of sturdy lines by identifying lines phenologic and morphologic properties by using growing parameters.

\section{Materials and Methods}

\subsection{Materials}

At the project seeds belong to 38 sweet maize inbred lines obtained from S5 stub lines whose inbreeding programs have been going on, developed by Prof. Bayram SADE and Prof. Süleyman SOYLU from Selcuk University Agriculture Faculty Crop Science Department Konya/Turkey were used. In addition to these materials Lumina and Merit hybrid maize varieties used as standards. 


\subsection{Methods}

The study was conducted at S.U.A.F. Crop Science Department Prof. Abdulkadir AKCIN experimental area as four blocks according to "Augmented Experimental Design". The trials were settled down for a year during 2013 Konya, Turkey. Konya plain is located middle and south parts of middle Anatolian zone. The plain is rounded by Bozda $\breve{g}$ and Obruk plateau from north and north east, inner parts of Toros Mountains at south, Eregli plain at east, Takkeli, Gevele and Loras mountains at west. Konya plain is $80 \mathrm{~km}$ from North to South, $50 \mathrm{~km}$ from West to East. The most western point of plain is $32^{\circ} 20^{\prime} \mathrm{La}$, the eastern point is $37^{\circ} 06^{\prime} \mathrm{Lo}$. The endpoint of North is $38^{\circ} 08^{\prime} \mathrm{N}$, South is $37^{\circ} 06^{\prime} \mathrm{N}$ [5]. Also each line were represented unrepeated as a row, standard hybrid maize varieties took part repeatedly at each block. The soil of experimental area was treated, weeds were removed mechanically and seed bed was prepared. Seeds obtained from inbred lines were sowed at the second week of May. Each inbred line was sowed by hand to $5 \mathrm{~m}$ rows. Between of rows was set as $70 \mathrm{~cm}$, between of plants was set $25 \mathrm{~cm}$. The experimental area was fertilized according to soil analyses results as $18 \mathrm{~kg} / \mathrm{da} \mathrm{N}$ and $11 \mathrm{~kg} / \mathrm{da} \mathrm{P}_{2} \mathrm{O}_{5} .4 \mathrm{~kg}$ of $\mathrm{N}$ and all of P [DAP $\left.\left(16 \mathrm{~N}-46 \mathrm{P}_{2} \mathrm{O}_{5}\right)\right]$ were treated with sowing. Rest of $\mathrm{N}$ was treated during second weed control and progressive developing stages at the form of ammonium nitrate $(33 \% \mathrm{~N})$. Blocks were designed with $1 \mathrm{~m}$ intervals. The observations and measurements that were done at inbred lines were summarized below.

\section{Observations and Measurements}

To obtain lines growing parameters, measurements below done according to [6] and [1].

\section{Tasseling time (day)}

$50 \%$ of plants at each block tasseling duration since sowing recorded.

\section{Silking (day)}

$50 \%$ of plants at each block silking duration since sowing recorded.

\section{First ear height (cm)}

Distance from soil surface to first ear was measured at five plants of each row during tasseling time and recorded.

\section{Stem thickness ( $\mathrm{mm})$}

It is detected with a stick from first node nearby soil surface at five plants of row during tasseling time.

\section{Ear leaf angle $\left(^{\circ}\right)$}

Angle between stem and ear leaf was measured by a protractor at five plants of row during tasseling time.

\section{Plant leaf number}

Leaf number of five plants at each row was counted during tasseling time.

\subsection{Statistical Analyses and Assessment}

Variances obtained from research were analyzed according to "Augmented Experimental Design" with Jump 5.0.1 program. Variance analysis table of control groups, corrected terms of lines and corrected values of lines were tabulated.

\section{Result and Discussion}

\subsection{Tasseling time}

Variance analysis results of control varieties were given at Table 1. The longest tasseling time of varieties was obtained from Merit with value of 64,33 days, Lumina followed this with 63 days.

When values obtained from lines evaluated it is observed that longest tasseling time obtained from 14.20 coded line with 83 days, minimum tasseling time values were obtained from 14.34 and 14.35 coded lines with 71 days. Other lines tasseling times changed between those two values. 
TABLE I: Variance Analysis Table of Control Varieties Tasseling Time

\begin{tabular}{lcccc}
\hline \multicolumn{1}{c}{ Variation Source } & Degree of Freedom & Sum of Square & Mean of Square & F \\
\hline Between Blocks & 2 & 26,33 & 13,165 & 2,6629 \\
Between Control Varieties & 2 & 394,13 & 197,065 & 39,8563 \\
Variety & 36 & 558,96 & 15,527 & 3,1403 \\
Error & 3 & 14,83 & 4,94 & - \\
General & 43 & 994,25 & 230,697 & - \\
\hline \hline
\end{tabular}

When lines compared to control varieties it is observed that 4.24.3 (69,67 days), 4.1.2 (65,17 days), 4.27.3 (82,67 days), 4.4.3 (81,17 days) and 4.21.1 (79,67 days) coded maize inbred lines get higher values than Merit (64,33 day) who has the highest value of control group. General values obtained from lines and control groups change between 60,67 and 82,67 days. [7] reported that tasseling time values change between 41,0-52,3 days at the study that was conducted with inbred maize lines.

\subsection{Silking duration}

Variance analysis table of control varieties Table 2 was given below. The longest silking value of control group was obtained from Merit with 73,67 days, Lumina followed this with 71,67 days.

TABLE II: Variance Analysis Results of Silking Duration Belong To Control Varieties

\begin{tabular}{lcccc}
\hline \multicolumn{1}{c}{ Variation Source } & Degree of Freedom & Sum of Square & Mean of Square & F \\
\hline Between Blocks & 2 & 26,33 & 13,165 & 2,6629 \\
Between Control Varieties & 2 & 394,13 & 197,065 & 39,8563 \\
Variety & 36 & 558,96 & 15,527 & 3,1403 \\
Error & 3 & 1,50 & 0,500 & - \\
General & 43 & 980,92 & 226,257 & - \\
\hline \hline
\end{tabular}

When values obtained from lines it is observed that the longest silking was obtained from 14.27 coded line with 89 days, minimum silking was obtained from 3.7, 13.34, 14.35 coded liens with 81 days. 4.11 .3 (89 days) coded line gained standard varieties significantly by silking with 89 days. 4.6 .4 coded line became fourth with 63 days, the lowest values of the group were 4.14.1 and 4.26.2 with 41 days. Values obtained from standards and lines were changed between 89 and 41 days. Silking is important for fertilization and grain formation. Sweet maize varieties are classified as early maturing, normal early maturing and late maturing time varieties. It is reported that silking depends on variety and sowing time. Environmental factors, sowing density, nitrogen douse are also effective on this parameter [8].

\subsection{First ear height}

Variance analysis values of first ear height were given at Table 3. The highest first ear height value of control varieties of study was obtained from Lumina with value of $48,69 \mathrm{~cm}$. Merit followed this with value of $57,78 \mathrm{~cm}$.

TABLE III: Variance Analysis Table Of Control Varieties First Ear Height Values

\begin{tabular}{lcccc}
\hline \multicolumn{1}{c}{ Variation Source } & Degree of Freedom & Sum of Square & Mean of Square & F \\
\hline Between Blocks & 2 & 60,90 & 30,450 & 4,3333 \\
Between Control Varieties & 2 & 209,39 & 104,695 & 221,2355 \\
Variety & 36 & 1689,67 & 46,935 & 98,4329 \\
Error & 3 & 318,59 & 106,197 & - \\
General & 43 & 2278,55 & 347,538 & - \\
\hline \hline
\end{tabular}

When values obtained from lines evaluated it is observed that 14.26 coded line has the highest first ear height value with $86,50 \mathrm{~cm} .3 .8$ and 14.21 coded lines followed it with of $80,90 \mathrm{~cm}$ and $77,50 \mathrm{~cm}$. When values obtained from lines compared to control varieties it is observed that $4.25 .1(64,10 \mathrm{~cm}), 4.24 .3(61,10 \mathrm{~cm})$ and 4.13.1 $(59,56 \mathrm{~cm})$ coded lines gained both control varieties significantly and got highest values. General values 
of first ear height of lines and varieties changed between $64,10 \mathrm{~cm}$ and $34,10 \mathrm{~cm}$. Ear height is very important especially from agricultural mechanization way. Being close to soil surface of main ear makes harvest difficult. Being ear to top parts of plant cause lying of plant especially variety whose stem is weak [9].

\subsection{Stem thickness}

Variance analysis results are given Table 4 below. Highest stem thickness obtained from control varieties is $1,82 \mathrm{~cm}$ from Merit and Lumina followed it with value of 1,64. When values obtained from lines evaluated it is observed that highest stem thickness value was obtained from 14.35 coded line with $2,32 \mathrm{~cm} .14 .21$ and 14.30 coded lines followed this value with $2,29 \mathrm{~cm}$ and $2,19 \mathrm{~cm}$ respectively.

TABLE IV: Variance Analysis Table Of Control Varieties Stem Thickness Values

\begin{tabular}{lcccc}
\hline \hline \multicolumn{1}{c}{ Variation Source } & Degree of Freedom & Sum of Square & Mean of Square & F \\
\hline Between Blocks & 1 & 0,2089 & 0,2089 & $2809^{*}$ \\
Between Control Varieties & 2 & 0,1172 & 0,0586 & 0,0660 \\
Variety & 30 & 1,9825 & 0,0001 & $-660,8^{*}$ \\
Error & 1 & 0,0001 & 0,3336 & - \\
General & 34 & 2,3087 & & - \\
\hline \hline
\end{tabular}

*Differences between varieties became important level of $5 \%$.

The lowest values of group were obtained from 3.7 and 14.16 coded lines with $1,06 \mathrm{~cm}$ and $0.84 \mathrm{~cm}$. When lines compared to controls it is observed that 4.13.1 $(2,39 \mathrm{~cm}), 4.5 .2(2,09 \mathrm{~cm})$ and $4.25 .1(2,03 \mathrm{~cm})$ coded lines gained Merit significantly who has highest stem thickness value $(1,82 \mathrm{~cm})$ of control group. Lumina gained 4.26.4 $(1,21 \mathrm{~cm}), 4.4 .1(1,11 \mathrm{~cm})$ and $4.4 .3(1,07 \mathrm{~cm})$ coded lines significantly with $1,64 \mathrm{~cm}$ according to stem thickness parameter. General values obtained from controls and lines for this parameter changed between 2,39 $\mathrm{cm} 1,07 \mathrm{~cm}$. At a study that was conducted with similar genotypes at the same environmental conditions by [10] stem thickness values of lines changed between $2,05 \mathrm{~cm}$ and $2,2 \mathrm{~cm}$, of hybrids changed between $2,15 \mathrm{~cm}$ and $2,44 \mathrm{~cm}$.

\subsection{Leaf angle}

Variance analysis table of control varieties was given below (Table 5). Highest leaf angle value of control group was obtained from Lumina with $48,78^{\circ}$, Merit followed it with $45,75^{\circ}$.

TABLE V: Variance Analysis Table of Control Varieties Leaf Angle Values

\begin{tabular}{lcccc}
\hline \hline \multicolumn{1}{c}{ Variation Source } & Degree of Freedom & Sum of Square & Mean of Square & F \\
\hline Between Blocks & 2 & 24,00 & 12,001 & 0,4364 \\
Between Control Varieties & 2 & 20,99 & 10,496 & 0,3817 \\
Variety & 36 & 2199,97 & 61,110 & 2,2221 \\
Error & 3 & 82,50 & 27,501 & - \\
General & 43 & 2327,47 & 111,109 & - \\
\hline \hline
\end{tabular}

When values obtained from lines evaluated, it is observed that highest leaf angle value was obtained from $14.5,14.34$ and 14.35 coded lines with $49^{\circ}$, the lowest leaf angle value was obtained from 14.9 coded line with $23^{\circ}$. When lines compared to controls it is observed that 4.6.3 $\left(69,14^{\circ}\right), 4.4 .1\left(61,64^{\circ}\right)$ and $4.26 .2\left(58,10^{\circ}\right)$ coded varieties gained Lumina $\left(48,78^{\circ}\right)$ who has highest leaf angle value. 4.22.1 $\left(39,1^{\circ}\right), 4.27 .1\left(37,1^{\circ}\right)$ and 4.4.3( $19,14^{\circ}$ ) coded lines formed last third values of group by leaf angle value, falling behind Lumina $\left(48,78^{\circ}\right)$ and Merit $\left(45,75^{\circ}\right)$. General values of lines and controls changed between $19,14^{\circ}$ and $69,14^{\circ}$. [11] reported that; at the study that was conducted to observed genetic structure, and evaluate yield and yield components of some maize varieties in Adana; a lot of properties like ear number, leaf angle, grain yield are affected by a lot of genetic factors like additive gene effects.

\subsection{Plant leaf number}

Variance analysis table of control group was given below (Table 6). The highest plant leaf number value was obtained from Lumina with 10,24. Merit followed this value with 9,77. 
TABLE VI: Variance Analysis Table of Control Varieties Plant Leaf Number Values

\begin{tabular}{lcccc}
\hline \multicolumn{1}{c}{ Variation Source } & Degree of Freedom & Sum of Square & Mean of Square & F \\
\hline Between Blocks & 2 & 1,77 & 0,884 & 0,1765 \\
Between Control Varieties & 2 & 4,18 & 2,091 & 0,0655 \\
Variety & 36 & 37,33 & 1,037 & 0,1469 \\
Error & 3 & 0,81 & 0,270 & - \\
General & 43 & 44,09 & 4,282 & - \\
\hline \hline
\end{tabular}

When values obtained from lines evaluated it is observed that highest leaf number value was obtained from 14.21 coded line with $12,15,14.29(12,15)$ and 14.3(11,85) coded lines followed it. Lines above gained control varieties according to plant leaf number values. Plant leaf numbers of other lines changed between those values. When lines compared to control varieties it is observed that 4.13.1 (12,76), 4.12.2 (10,56) and 4.1.5 (10,36) coded lines gained Lumina $(6,74)$ who has the highest value by this parameter. 4.17.2 $(7,07), 4.5 .2(6,76)$ and 4.14.1 $(6,74)$ coded lines have lower plant leaf number value than Merit $(9,77)$ who has the lowest leaf number value of control varieties. Values obtained for this parameter changed between 12,76 and 6,74. [12] reported that leaf number changes between 10,5 and 15,8 for sugar maize. Values obtained from this research are compatible with those researchers' values.

\section{Acknowledgements}

This study was supported by S.U.B.A.P. (Selcuk University Scientific Research Projects Office) with project coded 13401006.

\section{References}

[1] M. Tezel, "Determination heredity parameters of yield and yield components of maize (Zea mays L.)" M.S. thesis, Dep. Natural and Applied Sciences Institute, Selcuk University, Konya, Turkey, 2007.

[2] O. Konuskan, "Researches on heredity of some agricultural and grain quality properties of dent maize (Zea mays indentata Sturt.) with diallel hybrid analysis" pHD thesis, Dep. Natural and Applied Sciences Institute, Cukurova University, Adana, Turkey, 2006.

[3] O. Konuskan, "Effect of plant density on yield and properties related yield at second product hybrid maize in Hatay/Turkey" M.S. Thesis, Dep. Natural and Applied Sciences Institute, Mustafa Kemal University, Hatay, Turkey, 2000.

[4] A. Öz, "Use of discriminant analysis for selection of hybrid maize parent lines", Turk J Agric For, vol. 36, pp. 533$542,2012$.

[5] R. Bozyigit, T. Tapur, "The effect of groudwaters for formation of obruk in Konya plain and around", Journal of Selcuk University Social Sciences, vol. 21, 20 pgs, 2009.

[6] Anonymous, "Analysis methods of crops", Natural and Applied Sciences Institute, Selcuk University, Master Lecture Notes, 2001.

[7] M. Altinbas, N. Algan, "Interactions of earliness, yield and yield components of hybrid maize" Journal of Anatolia, vol. 3, pp. 40-62, 1993.

[8] K. Sönmez, Ö. Alan, E. Kınacı, İ. Kutlu, Z. Basçiftçi, Y. Evrenosoğlu, "Plant, stub and yield properties of some sweet maize (Zea mays saccharata Sturt) varieties", Journal of Suleyman Demirel University Agriculture Faculty, vol. 8, pp. 28-40, 2003.

[9] C. Ö. Egesel, H. Turhan, F. Kahrıman, P. Özkan,'Investigation of some sweet maize (Zea mays saccharata Sturt.) genotypes yield and properties" in Turkey VII. Crops Congree, 2007, vol. 1, pp. 206-209.

[10] İ. Cerit, "Determination of grain yield and some agronomic characteristics of single cross bred, double cross bred and third cross bred obtained from homozygous dent maize (Zea mays indentata Sturt.) lines" M.S. thesis, Dept. Natural and Applied Sciences Institute Crop Science Department, Cukurova University, 2006.

[11] H. M. Sen, "Heredity of some agronomic properties of six dent maize pure lines diallel progeny", pHD thesis, Dept. Natural and Applied Sciences Institute Crop Science Department, Cukurova University, 1999.

M. M. Williams, "Sweet Corn Growth and Yield Responses to Planting Dates of the North Central United States" Hortscience, vol. 43, pp. 1775-1779, 2008. 